\title{
Identification of hybrid formulae of a few willows (Salix) using ovule numbers
}

\author{
Alexander M. Marchenko' and Yulia A. Kuzovkina ${ }^{2 *}$ \\ 'Russian Park of Water Gardens, Moscow, Russia \\ ${ }^{2}$ Department of Plant Sciences, University of Connecticut, Storrs, CT, USA \\ * Corresponding author: Yulia A. Kuzovkina, E-mail: jkuzovkina@uconn.edu
}

\begin{abstract}
Salix is a genus of considerable taxonomic complexity, and accurate identification of its species and hybrids is not always possible. Quantification of ovules was used in this study to verify the parentage of a few hybrids of Salix. It has been shown that ovule numbers in willow hybrids are the mean of the ovule numbers of their parents. The ovule index of a prostrate specimen of S. xcottetii affirmed that this was a hybrid of S. myrsinifolia Salisb. and S. retusa L., and the ovule index of the ornamental cultivar 'The Hague' affirmed that this was a hybrid of S. caprea L. and S. gracilistyla Miq. Finally, we also examined a confusing group, previously identified in North America as $S$. pentandra. The ovule indexes and other morphological characters indicated that there were four taxa among the studied specimens: S. pentandra, S. xmeyeriana, S. serissima Fernald, and a hybrid of S. serissima and S. fragilis that has not previously been described. It was concluded that quantification of ovules in willows is a reliable tool that can be used in willow taxonomy, genetics and population studies.
\end{abstract}

Keywords: Salix xcottetii, Salix 'The Hague', Salix xmeyeriana, taxonomy, ovary

\section{Introduction}

The Salix genus comprises approximately 450 species of deciduous or, rarely, semi-evergreen trees and shrubs, with numerous species, subspecies, varieties, and hybrids (Argus 2010). Salix is a genus of considerable taxonomic complexity, for several reasons. The willows are dioecious, so usually an individual plant does not provide the full range of reproductive structures that are important for identification. The nonconcurrent phenology of generative and vegetative structures makes it impossible to observe both morphological characters on one plant at the same time. Willow identification is also complicated by phenotypic variability during different developmental stages (stipules and leaf hairs may appear and disappear during the growing season) and habitat conditions (the size and thickness of leaves depends on the degree of exposure to sunlight) (Skvortsov 1999; Dickmann and Kuzovkina 2014). In addition, considerable individual variability and polymorphism mask the differences between species and species limits. Natural tendencies to hybridization, introgression, and allopolyploidy further complicate the taxonomy of willows (Wagner et al. 2020). Therefore, the precise identification of Salix at the species level is often difficult and not always possible.

Traditionally, willow identification was based on morphological characteristics. More recently, willow species have also been identified using cytological, genetic, chemical, and ecological distinctions (Argus 2010). Specific differences can sometimes be inferred through differential distribution of herbivores and parasites, as well as through differential resistance to diseases and insects. Research in the area of molecular biology is increasingly helpful in defining species limits and hybrid identification (Gramlich et al 2016, 2018).

One morphological character that is critical in willow identification is the number of the ovules present in the ovary of the flower. Chmelař (1977) was the first to recognize that in Salix the number of ovules per ovary represents a fundamental phylogenetic characteristic. He analyzed the ovule numbers for about 120 Salix taxa and concluded that these parameters were consistent for different species. Chmelař demonstrated the stability of this character by estimating the variability of 
ovule numbers in different catkins within an individual plant, between individuals, within populations, and between populations.

Following Chmelař's findings (1977), Argus (1986, 2010), Valyagina-Malutina (2018) and Marchenko (2019) recorded ovule indexes - as minimum and maximum numbers of ovules per ovary - for many North American and Eurasian species. The most recent species descriptions in the protologues include the ovule numbers as an important morphological character (He 2019).

A recent study has confirmed the phylogenetic significance of ovule number in Salix and suggested its evolutionary patterns (Marchenko, 2019). Marchenko refined Chmelař's method by considering more comprehensive data. Important$l y$, he used not just one quantifier for the number of ovules per ovary, but two - the minimum and maximum numbers. Using both gives a more realistic representation of the range of ovule numbers characteristic for each species. Marchenko found that the percentage of ovaries in a catkin with ovule numbers in this range is meaningful for the identification of a given genotype. The knowledge of the number of ovules per valve (locule) further improves the precision of genotype recognition. These detailed calculations provide the means for differentiation between species, forms and varieties within species and even further - for the differentiation of divergent populations (populations from different provenances) and species ecotypes. New intraspecific classifications, including varieties and forms, were proposed for the widespread species S. alba L., $S$. babylonica L., S. fragilis L., and S. vitellina L., based on ovule numbers.

Quantification of ovules is also a useful method for the identification of the parents of hybrid species and hybrids themselves. Chmelař (1977) recognized the heritability of ovule numbers in willows and concluded that a hybrid has the mean of the ovule numbers of its parents. For example, it was observed that $S$. $\times$ salamonii, a hybrid of S. alba $\times$ S. babylonica has 4 ovules per valve. This number of ovules is consistent with what can be predicted from the average of the known parents: S. $\times$ salamonii ( 4 ovules) $=$ S. alba $(6$ ovules $) \times$ S. babylonica $(2$ ovules). Marchenko (2019) compared his deductions of the parentage of some thirty cold-hardy hybrid ornamental willows developed in Russia in the 1960s with their documented hybridization records; the results affirmed the viability of this approach.

The goals of this study were to verify the parentage of several willow hybrids cultivated in Europe and the United States using ovule index methodology. Each of these hybrids included various genotypes. First, the identity of Salix $\times$ cottetii Lagger ex A. Kern., an ornamental species cultivated worldwide as an ornamental in rock, alpine, and small urban gardens, was verified. Salix Xcottetii, described by A. Kerner in 1864 (Oesterr. Bot. Z. 14: 368. 1864) as a hybrid of S. myrsinifolia and S. retusa, is frequently cultivated worldwide. It is a low, usually prostrate or procumbent shrub, with long, trailing, somewhat ascending branches. Salix $\times$ cottetii has elliptic-to-oblong green leaves 2-4 cm long and about half as wide, finely serrulate along the margins. Catkins, which appear before the leaves in early spring, are cylindrical, $1.5-2.2 \mathrm{~cm}$ long. A recent morphological study revealed that there are a few different taxa cultivated under this name, two of them represented by female specimens: "true" S. Xcottetii, a prostrate female clone from Europe, and an upright plant called S. xcottetii 'Bankers', which was promoted for erosion control in the US (Kuzovkina et al. 2016a).

Second, the parentage of the ornamental cultivar S. 'The Hague' (syn. S. hagensis Hort; S. 'Hagensis'), a hybrid of S. caprea L. $\times$ S. gracilistyla Miq., was affirmed by ovule numbers. S. 'The Hague' is a vigorous female cultivar (Bean 1981). Its morphological characters are intermediate variations of both parents. $S$. 'The Hague' is an upright shrub up to $6.5 \mathrm{~m}$ tall with thick, gray brown, densely pubescent spreading stems. Leaves are oblong, 7-10 cm long, and 2-4 cm wide, glossy above and pubescent underneath, with noticeable acute stipules. Its conspicuous large catkins, up to $4-5 \mathrm{~cm}$ in length during anthesis and $7 \mathrm{~cm}$ in fruit, appear before the leaves in early spring and are very attractive. Salix 'The Hague' is cultivated as an ornamental plant in Europe and in North America (Newsholme 1992). There are a few morphologically different clones in cultivation under this name, including a clone with unusually branched catkins.

Third, a confusing group identified in the United States as S. pentandra L., which was recently determined to be a hybrid of S. xmeyeriana Rostk. (S. pentandra $\times$ S. fragilis) (Zinoviev, $2011 a, b, c)$, was included into this study. Salix xmeyeriana has been frequently misidentified in North America as S. pentandra. Previously S. pentandra was considered to have been introduced to about half of the states in the United States (Argus 2010). Zinovjev $(2011 \mathrm{a}, \mathrm{b}, \mathrm{c})$ doubted that S. pentandra was present in North America, for two reasons: first, because this species has been known to be represented only as pistillate plants in the flora area (Argus 2010), which excluded its sexual reproduction; and second, because S. pentandra branches are flexible and have a very low rooting ability, and so are not likely to be propagated by cuttings in natural settings. Zinovjev analyzed specimens identified as S. pentandra in North America and concluded that many of them are in fact S.xmeyeriana. A few specimens from North America, previously identified as $S$. pentandra or S. xmeyeriana, were analyzed using ovule counts to assert their identification.

\section{Materials and Methods}

\section{Plant material}

Live plants and herbarium specimens of S. xcottetii, S. 'The Hague', S. ×meyeriana and their supposed parents were procured for this study.

The following specimens were studied:

S. xcottetii: We used a herbarium specimen collected from a cultivated plant of S. $\times$ cottetii at the Botanic Garden of the Ural Branch of the Russian Academy of Sciences, Yekaterinburg, Russia. This is a female clone, previously positively identified as S. $\times$ cottetii based on morphological characters (Kuzovkina et al. 
2016a). We used two herbarium specimens of S. retusa L. specimen \#1 and specimen \#2 (collected and identified by A.K. Skvortsov; Austria; Herbarium of the Moscow Botanic Garden of the Russian Academy of Sciences, Moscow, Russia (MHA) and one herbarium specimen of S. myrsinifolia Salisb. (collected and identified by A.K. Skvortsov; near the city of Tarusa, Russia; MHA). Several herbarium specimens of S. xcottetii 'Bankers' were collected from cultivated plants at the University of Connecticut, $\mathrm{CT}$, US, which were originally procured from the National Plant Germplasm System of the United States Department of Agriculture (USDA/ARS) (PI 434285) and from the US nurseries.

S. 'The Hague'. Specimen \#1 is an herbarium specimen collected from cultivated plants at the Chadwick Arboretum, Ohio, US, originally procured from the private collection of C.M. Newsholme, Devon, UK; specimen \#2 is from Westonbirt Arboretum, UK; and specimen \#3 is from Bluestem Nursery, Canada.

We used two herbarium specimens of S. gracilistyla: specimen \#1 from T. Shimisu; Honshu, Pref. Nagano, Japan; 1976; MHA, and specimen \#2 from A. Yokota: Honshu, Pref. Miyagi, Japan; 1989; MHA. Catkins of S. caprea L. were collected from a live tree in Pushkino, in the Moscow region, Russia.

S. xmeyeriana Rostk. Seven specimens initially identified as S. pentandra or S. xmeyeriana, were selected for the analyses (Table 1). In addition, a synthetic female hybrid, 'Teatral 'naya', was included into the analysis for comparison.

Table 1

Ovules count. Two catkins per specimen were used for analyses and the mean ovule counts were recorded. The counts were made for all well-developed capsules (without abnormalities) in the catkin, using reflected and transmitted light microscopy and a magnifying lens. Morphological characteristics of the plants were documented to confirm their identifications.

When unripe capsules were used, counts were made by forcibly opening immature ovaries and counting the number of ovules present in the valves. When ripe opened capsules were used, counts were based on the number of funiculi (from both undeveloped ovules and developed seeds) in the valves (Figure 1). To prevent damage to the ovules and funiculi during the opening of the ovary or capsule, the opening was performed along the central vein of the carpel.
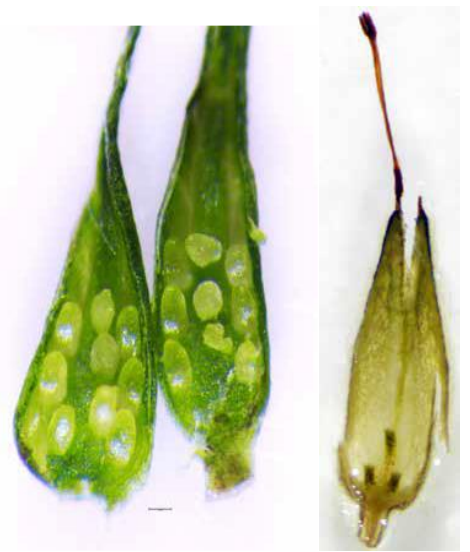

Figure 1. Left: Two valves of the ovary of S. eriocephala 'Russeliana' forcibly opened before fertilization: pubescence has not yet developed, and as a result the ovules can be easily counted. Right: One valve of the ovary of S. gracilistyla after seed dispersal: three funiculi are clearly distinguishable.

The specimens of S. pentandra and S. xmeyeriana, included into the analyses.

\begin{tabular}{|c|c|}
\hline Specimens & Description \\
\hline Specimen \#1 & S. pentandra (Arnold Arboretum, Harvard University, Boston, US, A) \\
\hline Specimen \#2 & $\begin{array}{l}\text { S. pentandra (W.L.G. Edson; 0-742, Highland Park, Rochester, NY, US, collected May 7, 1918, identified as S. ×meyeriana by A. } \\
\text { Zinovjev, 2013, A) }\end{array}$ \\
\hline Specimen \#3 & $\begin{array}{l}\text { S. pentandra (W.L.G. Edson; 0-743; Highland Park, Rochester, NY, US, collected May 7, } 1918 \text { and identified as S. ×meyeriana by A. } \\
\text { Zinovjev, 2013, A) }\end{array}$ \\
\hline Specimen \#4 & $\begin{array}{l}\text { S. ×meyeriana (A. Zinovjev \& I. Kadis; 2138, from a plant on northern Upper Mystic Lake (19 Lakeview Rd.) 42.44443-71.14308, } \\
\text { planting in Winchester, Middlesex County, MA, US, collected } 6 \text { May } 2011 \text { and described in Zinovjev (2011a)) }\end{array}$ \\
\hline Specimen \#5 & S. pentandra 'Aberdeen Selection' was obtained from USDA NRCS Aberdeen Plant Materials Center, Idaho, US; 20 November 2019 \\
\hline Specimen \#6 & $\begin{array}{l}\text { S. 'Teatral 'naya' (S. pentandra } \times \text { S. fragilis) was obtained from Pushkino, in the Moscow region, Russia (Marchenko, 2017). } \\
\text { Standard and duplicates for this cultivar are deposited in the Royal Horticultural Society Herbarium, Wisley, UK (WSY0108925, } \\
\text { WSY0108926, WSY0108927), the United States National Herbarium, Washington DC, US (NA0102513, NA0102514, NA0102515), } \\
\text { and MHA }\end{array}$ \\
\hline Specimen \#7 & $\begin{array}{l}\text { S. pentandra (collected and identified by B. Nelson \& B. Little, } 312 \text { S. Elm St., St. Joseph, Illinois, US; July 22, 1971, identified as S. } \\
\text { xmeyeriana by A. Zinovjev, 2013, A) }\end{array}$ \\
\hline Specimen \#8 & $\begin{array}{l}\text { S. pentandra (collected and identified by W.T. Gillis; Michigan State University Campus, East Lansing, Ingham County, Michigan, } \\
\text { US, } 13 \text { May } 1978 \text {, identified as S. ×meyeriana by A. Zinovjev in } 2013 \text {, A) }\end{array}$ \\
\hline
\end{tabular}


The willow fruit is a capsule, formed by the fusion of two carpels. When ripe, each capsule opens along the central vascular bundles of the carpels - into two valves, consisting of the fused halves of each carpel. Ovules are located on the placenta, which is positioned in the middle of the lower section of the valve. Following fertilization, the ovules develop into seeds.

The number of ovules can be quantified in either female or androgynous plants. Male plants inherit and pass on the genetic information about the number of ovules characteristic of their lineage. Therefore, when identifying a male parent of a hybrid, the number of ovules known for female representatives of the species were used in the calculation.

Because some ovules do not develop into seeds, the number of seeds in a ripe capsule is not an accurate assessment of the number of ovules; instead, their funiculi were used for counts. (Funiculi sometime are called seed traces, but the term is misleading because not all ovules develops into seeds.)

There are two phenological phases during which it is possible to make reliable ovule counts. The best time is at the beginning of anthesis, when stigmas are becoming visible above the flower bracts, just before fertilization takes place. A microscope was used for ovule magnification during this phenological stage. After fertilization, numerous hairs develop in the capsule, making it more difficult to see and count the ovules. The second-best time is after seed dispersal. At this point it is possible to count the funiculi on the placenta; these attachment structures remain intact in mature capsules.

Live and herbarium specimens were used for ovule counts. When working with catkins from herbarium specimens, the catkins were soaked in hot water at about $90^{\circ} \mathrm{C}$ with small amount of detergent (for example, dish soap) for 15-30 minutes to soften the tissues.

Calculations. The number of ovules per ovary varies within a catkin; the ovule index was recorded as the range of ovules per ovary in a catkin (for example, 10-12, where 10 is the minimum and 12 is the maximum number). For each specimen we determined the percentages of ovaries with different numbers of ovules. For example, in one catkin of $S$. xcottetii there were 70 ovaries. We opened each ovary and counted the number of ovules or funiculi on each of the two valves. Data were recorded in the following format: $3 / 5(8)-1(1 \%)$, in which the first two digits, written with the forward slash, indicate the number of ovules on each of the two valves; the number in parentheses indicates the number of ovules per ovary; the number following the dash represents the number of ovaries in the catkin with the given range of ovule numbers; and the percentage given in parentheses represents the percentage of the ovaries in the catkin with this count. Thus, for a sample such as the following: $3 / 5$ (8) - 1 (1\%); 4/5 (9) - 3(5\%); 5/5 (10) - 29 (41\%); 5/6 (11) -17 (25\%); $6 / 6(12)-20(28 \%)$, the minimum number of ovules per ovary is 8 and the maximum is 12 , so the index is $8-12$, and this index is presented in the tables along with the percentages of ovaries with different number of ovules in the catkin.

When the ovule index was obtained by counting the ovules in a specimen, it was called the calculated ovule index. When it is obtained as a result of estimating the mean of ovule numbers for two parents it is called the predicted ovule index (Marchenko 2019). The ovule indexes for parent species were determined from the studied specimens and in a few cases were taken from published references.

\section{Results and Discussion}

Salix $\times$ cottetii. The results of the ovule numbers for $S$. $\times$ cottetii and its parents are presented in Table 2.

The predicted ovule index for S. $\times$ cottetii - a hybrid offspring of $S$. myrsinifolia (ovule index 10-15) and S. retusa (ovule index 6/9) is the mean of the ovule numbers for its parents (8-12), calculated as follows:

the mean of the minimum ovule numbers of the parents: $6+10=16 / 2=8$

the mean of the maximum ovule numbers of the parents: $9+15=24 / 2=12$

This coincided with the calculated ovule index found in the studied specimen of the "true" S. xcottetii (ovule numbers 8-12), asserting that this specimen of $S$. Xcottetii is in fact a hybrid of S. myrsinifolia and S. retusa, as was originally described by A. Kerner.

The morphological analyses of this specimen revealed some characters inherited from one parent and some intermediate character variations of both parents, confirming its hybrid origin (Table 3, Figure 2). For example, S. xcottetii has partially hairy ovaries, a discordant character variation common in hybrid species where one parent is characterized by glabrous and another by pubescent ovaries. 
Table 2

The percentages of the ovaries with a specific number of ovules in a catkin and the ovule index (min./max. number of ovules per ovary) in S. xcottetii, S. retusa and S. myrsinifolia.

\begin{tabular}{|c|c|c|c|c|c|c|c|c|c|c|}
\hline \multirow{2}{*}{ specimens } & \multicolumn{9}{|c|}{ No. of ovules per ovary } & \multirow{2}{*}{ ovule index } \\
\hline & 6 & 7 & 8 & 9 & 10 & 11 & 12 & 13 & 15 & \\
\hline S. $\times$ cottetii & & & $1^{*}$ & 5 & 41 & 25 & 28 & & & $8-12$ \\
\hline S. retusa Specimen \#1 & $6^{*}$ & 21 & 46 & 27 & & & & & & $6-9$ \\
\hline S. retusa Specimen \#2 & 25 & 61 & 9 & 5 & & & & & & $6-9$ \\
\hline S. myrsinifolia & & & & & 5 & 14 & 72 & 4 & 5 & $10-15$ \\
\hline
\end{tabular}

*all values in the shaded cells represent the percentage of ovaries with different numbers of ovules in the catkin; unshaded cells represent the absence of ovaries with a specific number of ovules in the catkin

Table 3

Comparisons of some morphological characters of S. xcottetii, S. retusa, and S. myrsinifolia.

\begin{tabular}{|c|c|c|c|}
\hline character & S. $\times$ cottetii & S. retusa & S. myrsinifolia \\
\hline inflorescence & $2.5 \mathrm{~cm}$ & $1.0-1.5 \mathrm{~cm}$ & $2.5-3.0 \mathrm{~cm}$ \\
\hline flower bracts & $\begin{array}{l}\text { similar to S. retusa; } \\
\text { dark-colored in the upper third part, truncate with } \\
\text { a notch above the central vein; } \\
\text { sparsely pubescent with long trichomes on both } \\
\text { sides, trichomes are numerous along the margin }\end{array}$ & $\begin{array}{l}\text { dark-colored in the upper part, } \\
\text { truncate with a notch above the } \\
\text { central vein; } \\
\text { sparsely pubescent on both sides }\end{array}$ & $\begin{array}{l}\text { oblong with dark pointed tip; } \\
\text { clothed with long trichomes }\end{array}$ \\
\hline ovary & $\begin{array}{l}\text { lanceolate with intermediate characteristics of } \\
\text { S. retusa and S. myrsinifolia: glabrous at the base, } \\
\text { but densely pubescent in the upper third before } \\
\text { transition to the style; pubescence begins in the } \\
\text { deepening formed at the site of the prophyll fusion }\end{array}$ & narrow-lanceolate, glabrous & $\begin{array}{l}\text { oblong-ovate on a long stipe; stipe } \\
\text { and ovary pubescent }\end{array}$ \\
\hline style(s) & long, entirely connate & $\begin{array}{l}\text { partially distinct, separated (bifid) in } \\
\text { the upper part; }\end{array}$ & entirely connate \\
\hline nectaries & solitary; large; linear; narrow or wide & one or rarely two & solitary; shorter than the stipe \\
\hline
\end{tabular}

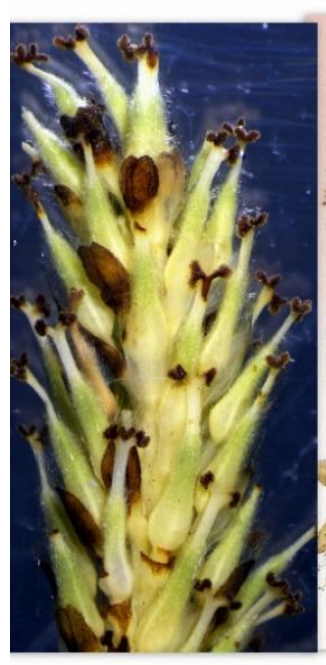

S. $x$ cottetii

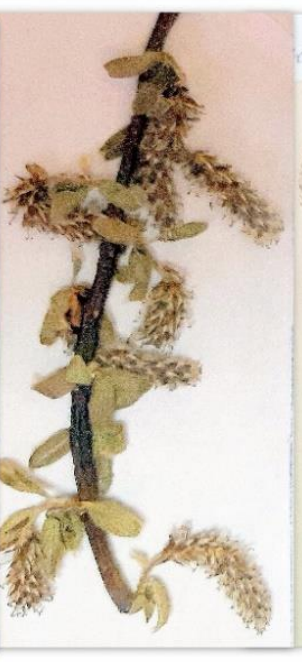

S. $x$ cottetii

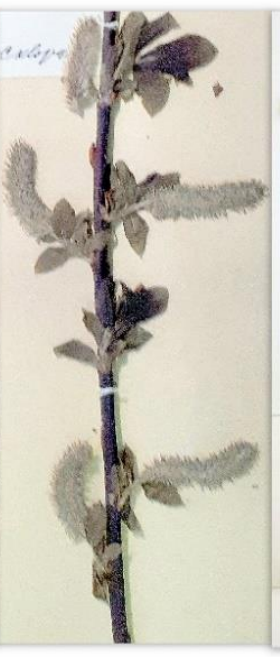

S. myrsinifolia

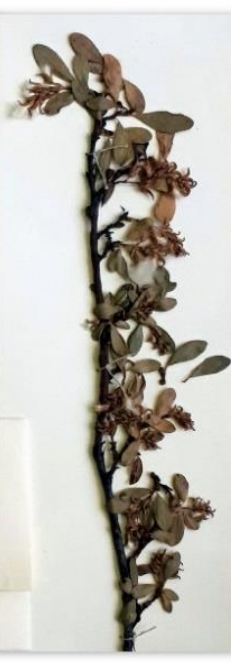

S. retusa

Figure 2

Catkins and flowering branchlets of S. xcottetii, S. retusa, and S. myrsinifolia. 
The studied specimens of $S$. $\times$ cottetii 'Bankers' had higher ovule numbers $(15-18,12-17)$ than $S$. xcottetii, suggesting that 'Bankers' was not a hybrid of S. myrsinifolia and S. retusa. The analyses of the ovule numbers of various Salix species suggested that it is likely a hybrid of S. eriocephala Michx. (ovule index 12-16 (Argus 2010)).

It was previously proposed that $S$. $\times$ cottetii 'Bankers' was a hybrid of S. eriocephala based on its upright habit, size (some specimens can reach up to $3 \mathrm{~m}$ high and wide), and morphological characters, including the presence of stipules, and bud scale morphology (Kuzovkina et al. 2016a).

S. 'The Hague'. The results of the ovule count of $S$. 'The Hague' and its parents are presented in Table 4. minimum ovule number, which was beyond the predicted ovule index. Its identity requires further elucidation.
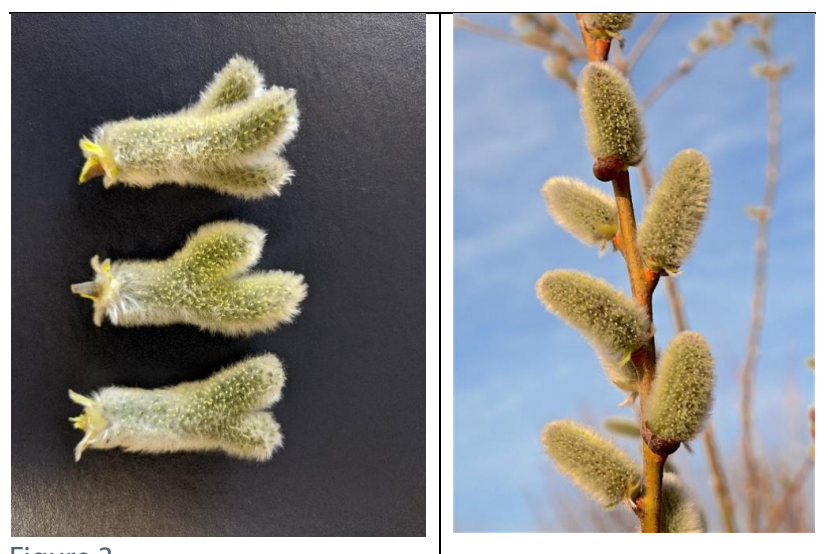

Figure 3

Catkins of S. 'The Hague' (left - a specimen with branched catkins; right - a specimen with unbranched catkins).

Table 4

The percentages of the ovaries with a specific number of ovules in a catkin and the ovule index (min./max. number of ovules per ovary) in S. 'The Hague', S. caprea and S. gracilistyla.

No. of ovules per ovary

ovule index

specimens

$\begin{array}{lllllllllllllll}4 & 5 & 6 & 7 & 8 & 9 & 10 & 11 & 12 & 13 & 14 & 15 & 16 & 17 & 18\end{array}$

\begin{tabular}{|c|c|c|c|c|c|c|c|c|c|c|c|c|c|c|c|c|}
\hline S. 'The Hague' Specimen \#1 & & & $3^{*}$ & 19 & 34 & 30 & 14 & & & & & & & & & $6-10$ \\
\hline S. 'The Hague' Specimen \#2 & & & & & 18 & 28 & 41 & 13 & & & & & & & & $8-11$ \\
\hline S. 'The Hague' Specimen \#3 & & & & & & 5 & 66 & 25 & 4 & & & & & & & $9-12$ \\
\hline S. gracilistyla Specimen \#1 & 15 & 11 & 74 & & & & & & & & & & & & & $4-6$ \\
\hline S. gracilistyla Specimen \#2 & & 5 & 95 & & & & & & & & & & & & & $5-6$ \\
\hline S. caprea & & & & & & & & & 18 & 8 & 14 & 9 & 34 & 11 & 6 & $12-18$ \\
\hline
\end{tabular}

with a specific number of ovules in the catkin

The predicted ovule index for S. 'The Hague' - a hybrid offspring of S. caprea (ovule numbers 12-18) and S. gracilistyla (ovule numbers 4-6) was 8-12 calculated as the following: the mean of the minimum ovule numbers of the parents: $12+$ $4=16 / 2=8$

the mean of the maximum ovule numbers of the parents: $18+$ $6=24 / 2=12$

The calculated ovule indexes, recorded from the three specimens of $S$. 'The Hague', varied slightly, but were within the range of the predicted ovule index, asserting that the studied specimens were likely to belong to the hybrid combination of $S$. caprea and S. gracilistyla. The analyses also revealed that there were a few clones with different ovule numbers (6-10 - for branched, 8-11 and 9-12 - for unbranched specimens). Specimen \#1, with branched catkins (Figure 3 ), had the lower
S. xmeyeriana. The predicted ovule index for S. xmeyeriana, the hybrid of S. pentandra and S. fragilis, using previously published ovule indexes for S. pentandra-18-22 (Argus, 2010), 16-24 (Valyagina-Malutina (2018), and 18-24 (Marchenko, 2019) and the ovule index 6-6 for S. fragilis (Marchenko 2019), was calculated as follows.

Using minimum numbers: $18+6=24 / 2=12 ; 16+6=22 / 2=$ $11 ; 18+6=24 / 2=12$.

Using maximum numbers: $22+6=28 / 2=14 ; 24+6=30 / 2$ $=15 ; 24+6=30 / 2=15$.

As a result, the predicted ovule indexes for $S$. xmeyeriana were $12-14 ; 11-15 ; 12-15$. They all are within the $11-15$ range.

The calculated ovule indexes of the seven specimens are presented in Table 5. 
Table 5

The percentages of the ovaries with a specific number of ovules in a catkin and the ovule index (min./max. number of ovules per ovary) in the specimens identified as S. ×meyeriana and its parents, S. pentandra and S. fragilis.

\begin{tabular}{|c|c|c|c|c|c|c|c|c|c|c|c|c|c|c|c|c|}
\hline \multirow{2}{*}{ specimens } & \multicolumn{15}{|c|}{ No. of ovules per ovary } & \multirow{2}{*}{ ovule index } \\
\hline & 6 & 8 & 9 & 10 & 11 & 12 & 13 & 14 & 15 & 16 & 17 & 18 & 19 & 20 & 22 & \\
\hline S. fragilis L. (Marchenko 2019) & $100^{*}$ & & & & & & & & & & & & & & & $6-6$ \\
\hline $\begin{array}{l}\text { Specimen \#1.S. pentandra L. (Ar- } \\
\text { nold Arboretum) }\end{array}$ & & & & & & & & & & & 27 & 56 & 4 & 9 & 4 & $17-22$ \\
\hline $\begin{array}{l}\text { Specimen \#2. S. serissima (S. pentan- } \\
\text { dra; Edson; S. ×meyeriana; Zinovjev; } \\
\text { 0-742; Rochester, USA) }\end{array}$ & & & & & & & & & 12 & 80 & 8 & & & & & $15-17$ \\
\hline $\begin{array}{l}\text { Specimen \#3. S. serissima (S. } \\
\text { pentandra; Edson; S. ×meyeriana; }\end{array}$ & & & & & & & & & & & & & & & & \\
\hline Zinovjev; 0-743; Rochester, USA) & & & & & & & & & 5 & 73 & 22 & & & & & $15-17$ \\
\hline $\begin{array}{l}\text { Specimen \#4. S. ×meyeriana (Zino- } \\
\text { vjev, Winchester, USA) }\end{array}$ & & & & & 4 & 25 & 31 & 30 & 4 & 6 & & & & & & $11-16$ \\
\hline $\begin{array}{l}\text { Specimen \#5. S. ×meyeriana (S. } \\
\text { pentandra L. 'Aberdeen Selection'; } \\
\text { Idaho, USA) }\end{array}$ & & & & & 5 & 22 & 39 & 17 & 17 & & & & & & & $11-15$ \\
\hline $\begin{array}{l}\text { Specimen \#6. Salix,Teatral'naya' ( } \text {. } \\
\text { pentandra } \times \text { S. fragilis) or } S . \times \text { mey- } \\
\text { eriana; Pushkino, Moscow region, } \\
\text { Russia) }\end{array}$ & & & & & 5 & 50 & 28 & 17 & & & & & & & & $11-14$ \\
\hline $\begin{array}{l}\text { Specimen \#7. S. serissima } \times \text { S. fragilis } \\
\text { (S. pentandra; Nelson \& Little; S. } \\
\text { ×meyeriana; Zinovjev, Illinois, USA) }\end{array}$ & & 6 & 30 & 47 & 15 & 2 & & & & & & & & & & $8-12$ \\
\hline $\begin{array}{l}\text { Specimen \#8. S. serissima } \times \text { S. fragilis } \\
\text { (S. pentandra; Gillis; S. } \times \text { meyeriana; } \\
\text { Zinovjev, Michigan, USA) }\end{array}$ & & & & 6 & 37 & 57 & & & & & & & & & & $10-12$ \\
\hline
\end{tabular}

*all values in the shaded cells represent the percentage of ovaries with different numbers of ovules in the catkin; unshaded cells represent the absence of ovaries with a specific number of ovules in the catkin

Based on the analyses of the ovule numbers, the following four taxa were identified: S. pentandra (ovule index 17-22), S. serissima (15-17), S. xmeyeriana (11-15 and 11-16), and a putative hybrid of S. serissima and S. fragilis (8-12 and 10-12).

The calculated ovule index 17-22 in specimen \#1 identified as S. pentandra was within the range of the previously reported values for this species (Argus 2010; Valyagina-Malutina 2018; Marchenko 2019), asserting its identification. Unfortunately, the label on the herbarium specimen does not have any information about origin of the specimen, except its name. According to Zinovjev (2011 a, b), a plant cultivated as S. pentandra at Arnold Arboretum (accession 95-1990) was a hybrid of S. pentandra, representing a different, staminate clone.

Specimens \#2 and \#3, represented by two accessions from Rochester, NY, US, which were previously identified first as $S$. pentandra and then as $S$. xmeyeriana, had the calculated ovule index (15-17) intermediate between those of S. pentandra and
S. xmeyeriana. The review of the ovule indexes for North American willows published by Argus (2010) revealed that this observed value was within the range of $S$. serissima Fernald (12-16), a species closely related to S. pentandra (Argus 2010; Skvortsov 1960). A morphological character observed in the studied specimens of S. serissima was the persisting cataphylls on the young shoots, in contrast to S. pentandra, in which cataphylls fall off promptly upon the expansion of the shoot.

The calculated ovule index (11-16) affirmed the identity of specimen \#4, previously identified and described by Zinovjev (2011b) as S. xmeyeriana. This specimen was discovered by Zinovjev on private property located on the shore of the Upper Mystic Lake in Winchester, Middlesex County, Massachusetts. According to the owner, this willow was purchased at a local nursery and planted in the early 1960s. It is a large tree with a trunk diameter of $83 \mathrm{~cm}$. Zinovjev found some freshly dropped brittle branchlets under the tree and suspected that the tree 
was not S. pentandra, since S. pentandra twigs are not brittle, and are generally not found on the ground. The leaves of this tree were broad and shiny, resembling those of S. pentandra, but the stipules, at least in young leaves, were better developed, the catkins were loose, and the flowers had bracts with long white hairs, all as in S. xmeyeriana. These branchlets rooted easily, asserting the identity of the tree as $S$. xmeyeriana.

Specimen \#5, received as S. pentandra L. 'Aberdeen Selection', was also identified as $S$. $\times$ meyeriana based on its calculated ovule index of 11-15. This cultivar was released by the USDA NRCS Aberdeen Plant Materials Center, Idaho, US, in 1998 as a pre-varietal germplasm (USDA-NRCS 2012). It was selected from a collection of plants proposed for windbreaks at the Center. The original plant material was collected in the upper Midwest of US from naturalized stands of European lineage. Thus, it would be unlikely that this selection was represented by S. pentandra, which is propagated mostly by seeds. It is worth noting that the branchlets of this specimen were fragile, asserting that this cultivar represented $\mathrm{S}$. xmeyeriana.

Specimen \#6, represented by S. 'Teatral 'naya', had a calculated ovule index of 10-16, which was within the range of the predicted ovule index for S. xmeyeriana (11-15). Salix 'Teatral 'naya' was another synthetic hybrid of S. pentandra $\times S$. fragilis produced in the Yekaterinburg Botanical Garden, Yekaterinburg, Russia (Marchenko 2017, 2019) along with 'Sverdlovskaja blestjaszczaja', which was studied by Zinovjev (2011c). Both cultivars represented the progeny from a cross made by V. Shaburov in the in the 1960s. Salix 'Teatral 'naya' also looked very similar to the specimens identified here as $S$. xmeyeriana (specimens \# 4 and 5). Salix'Teatral 'naya' is a female cultivar with catkins that are loose and narrow compared to S. pentandra catkins. Its capsules were much smaller than those of S. pentandra. Morphologically, the synthetic hybrid 'Sverdlovskaja blestjaszczaja' and S. 'Teatral 'naya' occupied an intermediate position between both parents.

Speciments \#7 and \#8 were collected in two different locations, in Illinois and Michigan. They were identified originally as S. pentandra, and later, in 2013, as S. xmeyeriana. They had the lowest ovule indexes among all studied specimens $-8-12$ and $10-12$. These low ovule numbers could be found in a hybrid of S. serissima (12-16) and another species with a low ovule index, for example S. fragilis (6-6). The predicted ovule index for such hybrid would be $9-11$, calculated as following:

the mean of the min. ovule numbers of the parents: $12+6=18: 2=9$

the mean of the max. ovule numbers of the parents: $16+6=22: 2=11$

There were no previous reports of a hybrid of S. serissima and $S$. fragilis in the literature, and it is possible that this hybrid has just been previously overlooked. According to Argus (2010), S. fragilis (as S. euxina) could occur throughout southern Canada and the United States, in the same regions as S. serissima. Thus, it is possible that hybridization could take place. Again, S. serissima and S. pentandra are closely related species and it is not surprising that their hybrids with $S$. fragilis could have been misidentified.
In summary, the analyses of the ovule numbers indicated that most of the specimens identified in North America as $S$. pentandra were in fact not that species. Some of the analyzed specimens were $S$. ×meyeriana, asserting Zinovjev's suggestion. Also, the analyses affirmed Zinovjev's suggestion about the possibility that not all of North American specimens resembling S. pentandra were actually its hybrids (Zinovjev 2011a). He suggested that $S$. lucida, which has similar lustrous, broad leaves, could have similar to $S$. ×meyeriana hybrids. Noteworthy, previously Griggs (1905) reported the hybrids of $S$. lucida and $S$. fragilis from Ohio, which were distinguished from S. lucida by their dull foliage, but with large reddish-brown winter buds of S. luci$d a$. While no $S$. lucida hybrids were revealed during this investigation, it was found that some of the specimens previously labeled as $S$. pentandra were represented by S. serissima, a species closely related to $S$. lucida, and its hybrid.

Salix pentandra, S. serissima, and S. lucida belong to the section Salicaster Dumort. They are characterized by intensely lustrous leaves, an odorous resin, and male flowers with numerous stamens. All species in this section are highly ornamental, with compact, dense crowns and attractive, shiny foliage (Skvortsov 1960).

Skvortsov (1960) divided this section into two distinct groups: the pentandra group and the lucida group. Salix serissi$m a$ and S. pentandra belong to the pentandra group, and both species have many similar characteristics. Even through Zinovjev (2011c) stated that S. serissima is rarely associated with New World 'S. pentandra', a few specimens included in this investigation appeared to be S. serissima. This is not surprising, considering that $S$. serissima is morphologically similar to S. pentandra and the limited morphological characters did not reveal the differences. Some differences include bud shape and location, the type of trichomes on the leaf primordia in the bud and on the cataphylls, leaf color, and the presence of stipules, which may be missing in herbarium specimens.

According to Skvortsov (1960) late seed ripening and germination in the following spring, typical in the pentandra group, is associated with thick, stout catkins and unusually large mature capsules (7-10, up to $11 \mathrm{~mm}$ long at maturity). Importantly, the most distinct morphological differences of both hybrids $-S$. pentandra $\times$ S. fragilis (S. xmeyeriana) and $S$. serissima $\times S$. fragilis observed in the studied specimens - was the smaller sizes of the mature catkins and capsules and much shorter flower branchlets compared to their parents, S. pentandra and S. serissima.

\section{Conclusions}

Practical applications of the study. This investigation affirmed that the quantification of ovule numbers is a useful method that can be employed for F1 (two parent) hybrid identification in conjunction with traditional morphological and modern molecular techniques. Ovule quantification constitutes an important taxonomic character for distinguishing between various groups of genotypes and ovule 
numbers should be included in the descriptions of new willow taxa. For breeders, ovule count provides a reliable affirmation of the parents of hybrids and as well as for offering insights into the parentage of unknown progenies. Also, Salix hybrids in natural stands might not be readily recognized if morphological characters are often not expressed, or major distinguishing characters are under the control of one or two dominant genes (Hardig et al. 2000). The ovule count can offer an independent set of data that can be deployed as an additional marker to unveil F1 hybrid individuals. Ovule counts can also be valuable for taxonomic studies assisting in species identifications and providing clues as to whether species variation is inherent or due to hybridization.

\section{Acknowledgements}

We thank A.G. Zinovjev, Randolph, Massachusetts, US; O.V. Epanchintseva of the Botanic Garden of the Ural Branch of the Russian Academy of Sciences, Yekaterinburg, Russia; and Derek Tilley of the USDA NRCS Aberdeen Plant Materials Center, Idaho, US, for providing herbarium specimens and cuttings. We thank the staff of the Moscow Botanic Garden Herbarium of the Russian Academy of Sciences (MHA) for their help with herbarium collections and M. Dodge for providing photos. The anonymous reviewers are gratefully acknowledged whose comments improved the quality of the manuscript.

\section{References}

Argus GW (1986) The genus Salix (Salicaceae) in the southeastern United States. Syst. Bot. Monogr. 9. https://doi.org/10.2307/25027618

Argus GW (2010) Salix. In: Flora of North America Editorial Committee, eds. 1993+. Flora of North America North of Mexico. 12+ vols. New York and Oxford. Vol. 7 .

Bean WJ (1981) Trees and shrubs hardy in the British Isles, p. 246-312. 8th ed. Revised by D.L. Clarke. John Murray, London, UK

Belyaeva IV, Shaburov VI, Dyachenko AA (2000) Hybrid willow trees in decorative horticulture in the Central Urals. Bul. Main Bot. Gard. 180:102-109. [Rus sian].

Chmelař J (1977) Taxonomic importance of capsule seed number in the genus Salix L. The Journal of the Silesian Museum (Opava) - Series C (Dendrology) 26 (1):1-7. [Czech].

Dickmann D, Kuzovkina YA (2014) Poplars and Willows in the World (pp.8-91). In: Poplars and Willows: Trees for Society and the Environment (Eds. J.G. Isebrands and J. Richardson), FAO UN and CABI. https://doi.org/10.1079/9781780641089.0008

Gramlich SG, Sagmeister P, Dullinger S, Hadacek F, Horandl E (2016) Evolution in situ: hybrid origin and establishment of willows (Salix L.) on alpine glacier forefields. Heredity 116:531-541. https://doi.org/10.1038/hdy.2016.14

Gramlich SG, Wagner ND, Horandl E (2018) RAD-seq reveals genetic structure of the F2-generation of natural willow hybrids (Salix L.) and a great potential for interspecific introgression. BMC Plant Biology 18:317 https://doi.org/10.1186/s12870-018-1552-6.

Griggs RF (1905) The Willows of Ohio. Proceedings of the Ohio State Academy of Science V. IV(6), Special papers No. 11. Spahr and Glennn Printers, Columbus, Ohio. https://doi.org/10.5962/bhl.title.17185

Hardig TM, Brunsfeld SJ, Fritz RS, Morgan M, Orians CM (2000) Morphological and molecular evidence for hybridization and introgression in a willow ( $\mathrm{Sa}$ - lix) hybrid zone. Molec. Ecol. 9: 9-24.

https://doi.org/10.1046/j.1365-294x.2000.00757.x

Harris JG, Harris,MW (1994) Plant identification terminology: an illustrated glossary. Spring Lake Publishing, Spring Lake, Utah.

He L, Liao S, Applequist W, Chen S (2019) The valid publication of Salix suchowensis (Salicaceae). PhytoKeys 131: 27-35. https://doi.org/10.3897/phytokeys.131.37065

Kuzovkina YA, Epantchintseva O, Belyaeva IV (2016a) The application of scientific names to plants in cultivation: Salix $\times$ cottetii Lagger ex A.Kern. (Salicaceae). Skvortsovia 2(3): 32-43.

Kuzovkina YA, Dodge M, Belyaeva IV (2016b) Clarifying affiliations of Salix gracilistyla Miq. cultivars and its hybrids. HortScience. 51(4): 334-341. https://doi.org/10.21273/hortsci.51.4.334

Marchenko AM (2017) V.I. Shaburov's ornamental hybrid willows for northern climates. Moscow: Non Stop Publisher. [Russian]

Marchenko, A.M. 2019. Ovules and identification of willows (Salix). Moscow, Non-Stop. [In Russian].

Marchenko AM, Kuzovkina YA (2020a) Determination of hybrid formulae for a few willows (Salix L.) using ovule numbers. Skvortsovia 6(2): 12-14.

Marchenko AM, Kuzovkina YA (2020b) Nomenclature and taxonomy of Salix fragilis L., S. euxina I.V.Belyaeva and S. $\times$ fragilis L. Bul. Main Bot. Gard. 206:6876. [In Russian].

Meikle RD (1984) Willows and poplars of Great Britain and Ireland. Botanical Society of the British Isles, London.

Newsholme C (1992) Willows: The Genus Salix. B.T. Batsford, London.

Skvortsov AK (1960) Salix pentandra and related species. Trudy MOIP 3: 247-262. [In Russian].

Skvortsov AK (1999) Willows of Russia and adjacent countries. Taxonomical and geographical revision. University of Joensuu Faculty of Mathematics and Natural Sciences Report Series 39: 1-307.

USDA-NRCS (2012) Release brochure for Aberdeen selection of laurel willow (Sa lix pentandra). USDA-Natural Resources Conservation Service, Aberdeen Plant Materials Center. Aberdeen, ID. https://www.nrcs.usda.gov/Internet/FSE PLANTMATERIALS/publications/ idpmcrb11473.pdf; accessed 31 October 2020).

Valyagina-Malutina ET (2018) Willows of Russia. KMK, Moscow. [In Russian].

Wagner ND, He L, Horandl E (2020) Phylogenomic relationships and evolution of polyploid Salix species revealed by RAD sequencing data. Frontiers in Plant Science. Volume 11. https://doi.org/10.3389/fpls.2020.01077

Zinovjev AG (2011a) Willows of Massachusetts: A forgotten willow Salix $\times$ meye riana Rostk. ex Willd. (= S. pentandra $\times$ S. euxina) found in the Arnold Arboretum.

http://172.104.19.75/notes/salix_x_meyeriana/forgotten_willow.html; accessed October 31, 2020

Zinovjev AG (2011b) Willows of Massachusetts: Salix $\times$ meyeriana Rostk. (= S. pentandra $\times$ S. euxina) found in Winchester, eastern Massachusetts. http://172.104.19.75/notes/salix x meyeriana/meyeriana winchester.html; accessed October 31, 2020.

Zinovjev AG (2011c) Salix ×meyeriana (= Salix pentandra $\times$ S. euxina) - a forgot ten willow in Eastern North America. Phytotaxa 22: 57-60. https://doi.org/10.11646/phytotaxa.22.1.5 